\title{
EFFECTS OF PLANT LECTINS ON HUMAN ERYTHROCYTE AGGLUTINATION
}

Nadja Zubcevic ${ }^{1}$, Suljevic Damir ${ }^{1}$, Muhamed Focak ${ }^{1}$, Dunja Rukavina ${ }^{2}$

${ }^{1}$ Department of Biology, Faculty of Science and Mathematics, University of Sarajevo

${ }^{2}$ Department of Biology, Veterinary Faculty, University of Sarajevo

\author{
EFEITI BILJNIH LEITINA NA AGLUTINACIJU ERITROCITA \\ KOD LJUDI \\ Nađa Zubčević ${ }^{1}$, Suljević Damir ${ }^{1}$, Muhamed Fočak1, Dunja Rukavina \\ ${ }^{1}$ Odsek za biologiju, Prirodno-matematički fakultet, Univerzitet u Sarajevu \\ ${ }^{2}$ Odsek za biologiju, Veterinarski fakultet, Univerzitet u Sarajevu
}

\begin{abstract}
Plant lectins are carbohydrate binding proteins or phytohaemagglutinins present in most plants, especially seeds and tubers, which include cereals, potatoes and beans. Lectins have great significance in the diet because of their involvement in gastrointestinal difficulties and erythrocyte agglutination. Blood agglutination activity against $A, B, A B$ and $O$ groups was shown after exposing blood to extracts obtained from $55 \%$ of tested plants, while in $45 \%$ of plants, agglutination was absent. The results of our study have shown that in humans, $40 \%$ of plant extracts exhibited activity against $A, 40 \%$ of plant extracts exhibited activity against $B$, and $50 \%$ of plant extracts exhibited activity against $A B$ and O groups in humans. The concentration of plant lectins depends on the part of the plant. Lectins from the seeds of certain plants cause the greatest percentage of erythrocyte agglutination, while the lowest agglutination was caused by plant bulbs and leaves. However, lectins derived from all plant species of the family Fabaceae agglutinated erythrocytes of all blood types to some extent.
\end{abstract}

Keywords: lectins, agglutination, blood groups

\section{SAŽETAK}

Biljni lektini ili fitohemaglutinini su proteini koji vezuju ugljene hidrate prisutini u mnogim biljkama, posebno u semenkama i gomoljima žitarica krompira i mohunarki. Lektini imaju veliki značaj u ishrani zbog njihovog delovanja na gastrointestinalni trakt $i$ aglutinaciju eritrocita. Aglutinacija krvnih grupa ( $A, B, A B i O)$ se pojavila kod 55\% uzoraka na testirane biljke, dok je kod $45 \%$ uzoraka aglutinacija izostala. Rezultati naše studije su pokazali da 40\% biljnih ekstrakata lektina deluje na aglutinaciju krvne grupe A, 40\% ekstrakta deluje na aglutinaciju krvne grupe B, a po 50\% ekstrakta biljaka utiče na aglutinaciju krvnih grupa $A B i$ O. Koncentracija lektina zavisi od dela biljke. Lektini iz semenki odredenih vrsta su pokazali najveći uticaj na stepen aglutinacije eritrocita, dok je najmanji stepen aglutinacije prilikom korišćenja lukovica i listova. Primećeno je da lektini iz svih biljaka porodice Fabaceae utiču na aglutinaciju eritrocita kod svih krvnih grupa.

\section{INTRODUCTION}

Lectins are carbohydrate binding proteins present in most plants and in some animals. Lectins do not cause any antigenic stimulation within the immune system, but they have the basic capacity to bind analogously to an antibody (1). The specific capacity of lectins to bind with the cell surface mainly depends on the monosaccharides or simple oligosaccharides, which, when present, inhibit lectin associated reactions. They are involved in cellular interactions (2-3) and the phenomenon of biological recognition such as the binding of microorganisms to target tissues, protein
Ključne reči: lektini, aglutinacija, krvne grupe

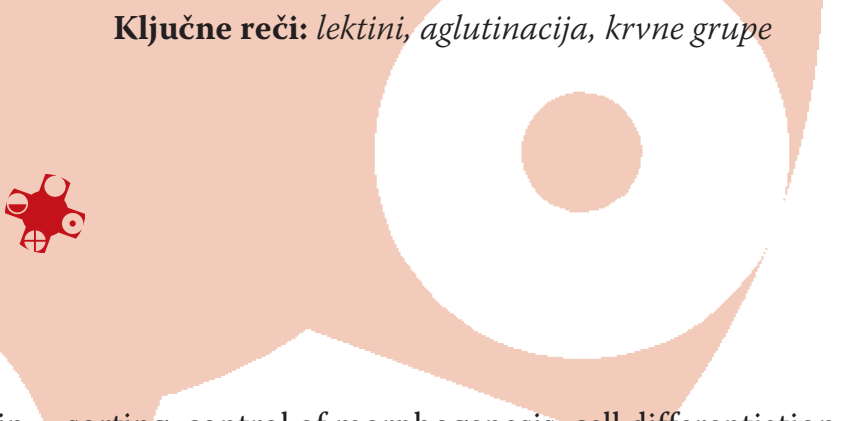

sorting, control of morphogenesis, cell differentiation, fertilization, leukocyte adhesion, metastasis and inhibition of natural killer cell activity against healthy cells (4).

These proteins are widely distributed in living organisms such as algae, animals, microorganisms, fungi and plants (5-7). Plant lectins have mostly been found in seeds and in almost all types of vegetative tissues, including fruits, bulbs, leaves, stems and roots (8-11). Plant lectins from the Fabaceae family that are not effectively degraded by digestive enzymes and that have 
an affinity for the surface epithelial cells of the gastrointestinal tract may be toxic (12). On the other hand, some lectins are slightly absorbed in the gastrointestinal tract and are relatively non-toxic in moderate concentrations (13). Lectins bind to glycosyl groups on the membranes of cells lining the digestive tract; this lectin binding is used as a potential tool for the specific targeting of drugs and for bioadhesive applications. Areas of epithelial cells and even whole zones are necrotized, which can be observed in biopsies of the mammal (14) and insect (15) intestines. However, when cells are treated with lectins in vitro, even in high doses, necrosis is not observed, although many other responses have been noted including mutagenesis (16), formation of vacuoles (17) and inhibition of exocytosis.

Over the past few decades, it has been reported that many lectins are toxic and inflammatory. Lectins are resistant to both heat and digestion. Some lectins are highly resistant to gastric acid and proteolytic enzymes (18). According to some studies, some foods containing lectins pass through the intestinal wall, which can result in the deposition of lectins in distant organs (19). Lectins are very active if consumed in fresh food, although activity does not decrease with heat treatment. Haemagglutination activity has been found in processed wheat germ agglutinin, peanuts and dry cereal (20), tomato lectin (12), and navy bean lectin (21), and lectins have been recovered intact in stool (20-21). Wheat gliadin, which causes celiac disease, contains a lectin like substance that binds to the human intestinal mucosa (22). Nephropathy might be caused or aggravated by wheat lectins (23). Wheat lectins are known to induce hyperplasia and hypertrophy of the small intestine and cause changes in body weight and in intestinal function in experimental rats (24). At high dietary levels, lectins cause severe damage to the structure of the small intestine (25-26) and lead to hypersensitivity of the immune system (27).

Recent studies have shown different lectin reactions toward the $\mathrm{ABO}$ blood type (28), while other studies show that lectins preferential for a particular $\mathrm{ABO}$ type are not found in food and that lectins with $\mathrm{ABO}$ specificity are more frequently found in non-food plants or animals (2930). Despite these criticisms, there seems to be a correlation between diet and blood type. Therefore, when food containing lectin proteins that are incompatible with one's blood type antigen are eaten, the lectins begin to agglutinate blood cells.

\section{MATERIALS AND METHODS}

\section{Blood collection from human subjects}

The blood samples for this analysis were obtained by venipuncture from healthy individuals of both sexes who have blood types $A, B, A B$ and $O(n=24)$.
Table 1. Percentage of agglutination ratio between blood types

\begin{tabular}{|c|c|c|c|c|c|}
\hline & $\mathbf{A}$ & $\mathbf{B}$ & $\mathbf{A B}$ & $\mathbf{O}$ & total \\
\hline Negative & 12 & 12 & 10 & 10 & $45 \%$ \\
\hline Positive & 8 & 8 & 10 & 10 & $55 \%$ \\
\hline$\%$ & 40 & 40 & 50 & 50 & \\
\hline
\end{tabular}

\section{Preparation of extracts}

A total of 20 different plant species which are found in the human diet were purchased. The plant materials were first thoroughly washed with tap water and then rinsed with distilled water. Different plant parts that were being used for isolating lectins were collected from the available sources and taxonomically identified. Portions $(1 \mathrm{~g})$ of the edible portions of each food were placed in a warring blender. Two millilitres of $0.9 \% \mathrm{NaCl}$ was added and the contents were homogenized for 1 to 3 minutes. The resulting suspension was filtered through cheesecloth, and the filtrate was then centrifuged at $10000 \mathrm{rpm}$ for 10 minutes to obtain a clear extract. The supernatant was separated and stored.

\section{Erythrocyte agglutination}

The samples were analysed using an "Olympus $\mathrm{CH} 2$ " microscope, while digital pictures were taken using an "Olympus DP12 Digital Microscope". A drop of blood of a specific blood type was mixed with a drop of extract and then observed using a microscope (100x magnification). A sample containing a drop of extract and a drop of $0.9 \%$ $\mathrm{NaCl}$ was examined as a control.

\section{RESULTS}

The percentage ratio of agglutination and the total number of plant species extracts with and without agglutination ability are presented in Table 1 . The results showed that lectins from $55 \%$ of the plant species studied caused the agglutination of a particular blood group, while lectins from $45 \%$ of plant species showed no agglutination. From the $55 \%$ of plant species where lectins were capable of agglutination, $40 \%$ agglutinated blood types A and B, while the remaining $50 \%$ agglutinated blood types $\mathrm{AB}$ and $\mathrm{O}$.

The studied plant species and plant parts as well as presence or absence of agglutination is presented in Table 2. It was found that the following nine plant species do not cause agglutination (45\%): grape, tomato, banana, walnut, carrot, pumpkin, lemon, garlic and onion. The lectins from beetroot caused blood type $\mathrm{O}$ agglutination, while those from apple caused blood type $A B$ agglutination. Furthermore, the lectins from cucumber cased blood type $A B$ and $\mathrm{O}$ agglutination. Cashew, melon, strawberry, soy, bean, pea, eggplant and potato caused agglutination in all cases.

Plant species whose seeds were used for the extraction of lectins, such as soy, bean and pea (with the exception of 
Table 2. Blood type agglutination and plant species

\begin{tabular}{|c|c|c|c|c|c|c|c|}
\hline \multirow{2}{*}{ PLANT NAME } & \multirow{2}{*}{$\begin{array}{l}\text { VERNACULAR } \\
\text { NAME }\end{array}$} & \multirow{2}{*}{ FAMILY } & \multirow{2}{*}{ PART USED } & \multicolumn{4}{|c|}{$\begin{array}{l}\text { BLOOD TYPE } \\
\text { AGGLUTINATION }\end{array}$} \\
\hline & & & & A & B & $\mathbf{A B}$ & O \\
\hline 1. Allium cepa & Onion & Amaryllidaceae & bulbs & - & - & - & - \\
\hline 2. Allium sativum & Garlic juice & Amaryllidaceae/ Liliaceae & bulbs & - & - & - & - \\
\hline 3. Anacardium occidentale & Cashew & Anacardiaceae & fruit & + & + & + & + \\
\hline 4. Beta vulgaris & Sugar Beet & Chenopodiaceae & leaf & - & - & - & + \\
\hline 5. Citrullus vulgaris & Watermelon & Cucurbitaceae & fruit & + & + & + & + \\
\hline 6. Citrus limon & Lemon & Rutaceae & fruit & - & - & - & - \\
\hline 7. Cucumis sativus & Cucumber & Cucurbitaceae & fruit & - & - & + & + \\
\hline 8. Cucurbita pepo & Pumpkin & Cucurbitaceae & seed & - & - & - & - \\
\hline 9. Daucus carota & Carrot & Apiaceae & fruit & - & - & - & - \\
\hline 10. Fragaria vesca & Strawberry & Rosaceae & fruit & + & + & + & + \\
\hline 11. Glycine $\max$ & Soyabean & Fabaceae & seed & + & + & + & + \\
\hline 12. Juglans regia & Walnut & Juglandaceae & kernel & - & - & - & - \\
\hline 13. Malus domestica & Apple & Rosaceae & fruit & - & - & + & - \\
\hline 14. Musa paradisiaca & Banana & Musaceae & fruit & - & - & - & - \\
\hline 15. Phaseolus vulgaris & Black kidney bean & Fabaceae & seed & + & + & + & + \\
\hline 16. Pisum sativum & Pea & Fabaceae & seed & + & + & + & + \\
\hline 17. Solanum lycopersium & Tomato & Solanaceae & fruit pulp & - & - & - & - \\
\hline 18. Solanum melongena & Eggplant & Solanaceae & fruit and seed & + & + & + & + \\
\hline 19. Solanum tuberosum & Potato & Solanaceae & bulb & + & + & + & + \\
\hline 20. Vitis vinifera & Green grapes & Vitaceae & fruit pulp & - & - & - & - \\
\hline
\end{tabular}

pumpkin), caused agglutination of erythrocytes of all blood types, while the plants whose fruit were used for the extraction of lectins showed different ability to cause agglutination. Plants such as watermelon, cashew, strawberry and eggplant agglutinated erythrocytes of all blood types, while lemon, carrot, banana, tomato and grape did not cause ag- glutination of erythrocytes. The bulbs used for the extraction of lectins (garlic and onion) did not cause agglutination of erythrocytes, and the lectins from the leaf of beetroot agglutinated blood type $\mathrm{O}$, as shown in Figure 1.

The plants from the Fabaceae and Anacardiaceae families agglutinated red blood cells in all four blood types

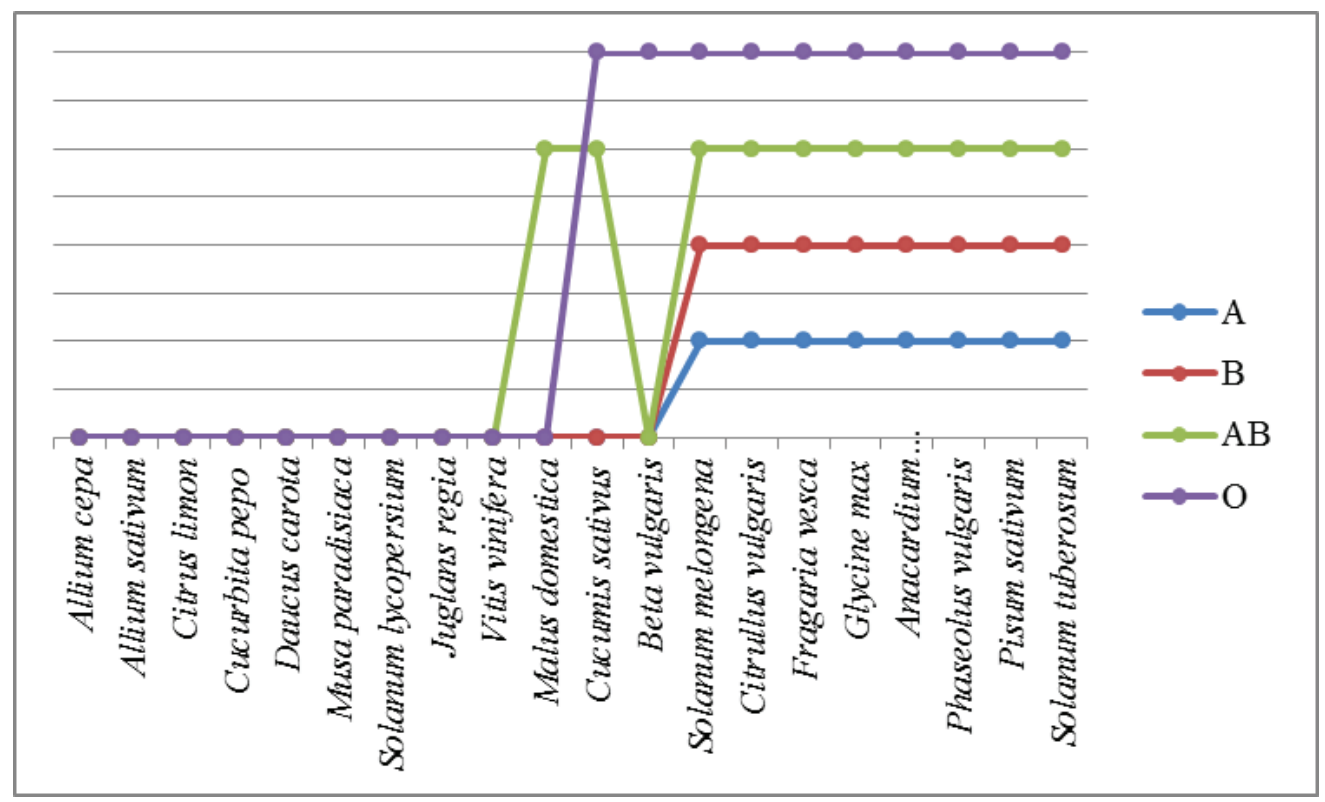

Figure 1. Plant species and agglutination in different blood types 


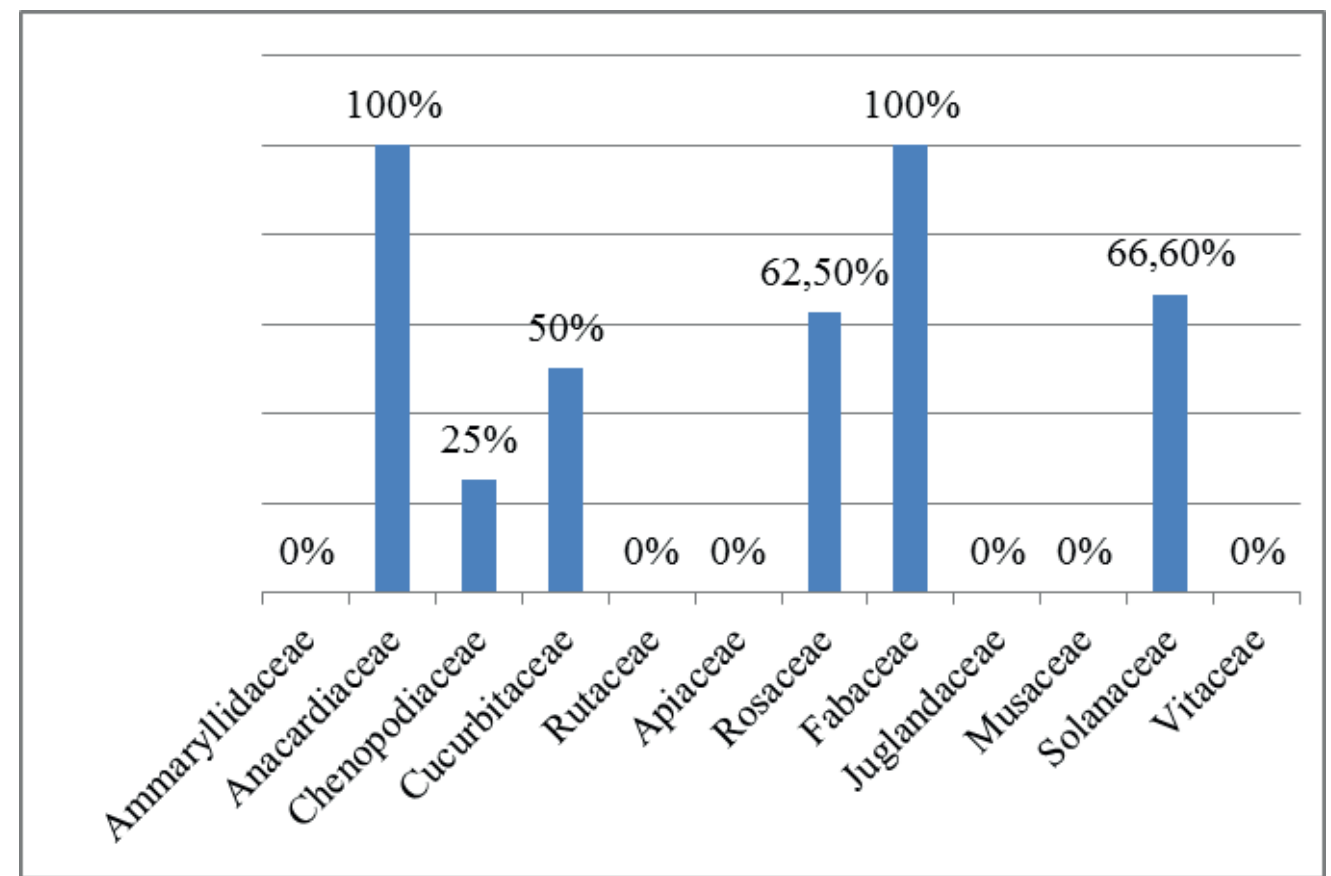

Figure 2. Correlation between percentage of agglutination and plant family

(100\%), while the plants from the Amaryllidaceae, Rutaceae, Apiaceae, Juglandaceae, Musaceae and Viaceae families had no effect on erythrocyte agglutination (0\%), as shown in Figure 2.

\section{DISCUSSION}

Some of the dietary lectins are heat-stable and react with the gastrointestinal tract, causing subclinical effects in humans, especially when used in large quantities (31). Lectins in excess can cause gastrointestinal damage, type2 IgG immune responses, mild allergies and haemagglutination. It is possible that lectins may not be responsible for short term toxicity caused by the consummation of a raw meal (32). Therefore, lectins play a key role in the daily life of people based on their geographic existence, genetic constitution and adaptability to specific plant products. The development of a lectin tolerance is the result of active immune mechanisms and both the development and maintenance of a lectin tolerance. Nutrition may be the source of antigens that aid in increasing the lectin tolerance of the immune system as well as in providing factors, including nutrients; they themselves might modulate immune maturation and responses and provide factors that influence intestinal microbiota (33). Allergenic proteins present in food may contain components that induce food intolerance or allergy (34). Research related to lectins in food and their interaction with the gastrointestinal tract reveal that there is a direct correlation between the evolution of blood types and food intake types (35). The development of blood groups is based on many factors such as genetic constitution, geographical and environmental factors and the adaptation to various food types from the early days of growth during evolution. Anthropologists recommended that the order of blood group development be based on the food habits of humans (28). This concept states that the first blood group evolved on earth was O: it belonged to the ancestors who hunted, made their own weapons and ate meat. The second blood group that evolved was blood group $\mathrm{A}$, who comprised pure vegetarians. Blood type $\mathrm{B}$ was the third blood type developed, which emerged as a result of migration and further climate change. People with this blood type were habituated to a diet that included meat and plants as well as dairy products. The final blood type to evolve was type AB (36).

In this study, it was established that a high percentage of plants (55\%) used in the human diet have the ability to cause agglutination of erythrocytes. Lectins from $40 \%$ of the plants tested had the ability to agglutinate blood group A, 40\% had the ability to agglutinate blood group $\mathrm{B}, 50 \%$ had the ability to agglutinate blood group $\mathrm{AB}$, and $50 \%$ had the ability to agglutinate blood group O. Nine plants did not show any lectin activities against any blood groups tested in our study. Some authors claim that the absence of lectin activity in these plants against blood groups has great evolutionary importance in the diversified tolerance development to these foods in the internal lining of the gastrointestinal tract from the mouth to the anus in humans. Studies have shown that lectins from the family Fabaceae usually cause agglutination. Three plant species, Pisum sativum, Phaseolus vulgaris, and Glycine max caused agglutination of erythrocytes from all blood groups. Lectins are found in abundance in le- 
gume seeds. Phaseolus vulgaris is an herbaceous annual plant grown worldwide for its edible beans, popular in both dry and green bean forms. The commercial production of beans is well distributed worldwide. Haemagglutinating activity in the processed Phaseolus vulgaris and Pisum sativum that we tested showed high lectin activity. It can be concluded that at least some lectins in food products will survive one or both degradative processes to interact with cells, secretions, and microflora of the digestive tract resulting in, as yet unknown, functional consequences. Extracts from Cucumis sativus (Cucurbitaceae) caused agglutination of the $\mathrm{AB}$ and $\mathrm{O}$ blood groups. Lectins from Musa paradisiaca (Musaceae) did not agglutinate human erythrocytes. Extracts from the fruit pulp of the plant Vitis vinifera (Vinaceae) did not agglutinate erythrocytes; however, lectins extracted from grape skin caused agglutination of all blood types, as shown in one previous research study (35). The different agglutination abilities of one plant species occur because lectins are present in various plant parts in different concentrations. It is evident that most lectins are present in plant seeds and fruit, while lower concentrations are found in plant roots, stems and leaves. We observed that lectins from seeds (soy, beans and peas) agglutinated all erythrocyte blood types, and lectins from fruit agglutinated different blood types.

The subject of the lectin pathways and effects on organisms is very broad and deserves more discussion. Although lectins are identified as potential toxins, there are some lectins that are beneficial to the body. Lectins provide a diverse and an increasing number of applications. For example, the ability of lectins to bind selectively to carbohydrate residues of glycoproteins makes these proteins useful as differentiating markers to study cancer cells (37) and to characterize differentiation among stem cells (38). Several lectins are reported to possess different biological activities that include anti-bacterial (39), anti-fungal (40), anti-HIV (41), and immunomodulative effects (42) as well as anti-proliferative and mitogenic stimulation for specific cell types. Lectins are also being studied as tools for drug delivery (43). With the numerous and increasing applications of lectins, it is imperative and relevant to identify novel plant sources of lectins.

\section{CONCLUSIONS}

The identification of the plant parts that have different concentrations of lectin is important from the aspect of human nutrition due to gastrointestinal problems caused by food containing a large amount of lectins and the ability of lectins to agglutinate human erythrocytes of different blood groups. A large number of plants used in food contain lectins and the largest concentration of lectin is usually found in the plant's seeds. The proper differentiation and knowledge of plant species is important from the aspect of nutrition, and all present selection for a blood type diet.

\section{Authors' contributions}

Nađa Zubčević, Bachelor of Biology, Biochemistry and Physiology field designed experiments as well as collected and prepared blood samples and plant specimens. Dr. Sci. Damir Suljević and Muhamed Fočak, MSc. of Biochemistry and Physiology, conducted the analysis to determine the presence or absence of agglutination after mixing blood with the water extract of plants. Dr. Sci. Dunja Rukavina performed research in the laboratory, explored other authors' research and compared their data with our own.

\section{Conflict of interest}

We do not have any conflicts of interest to report.

\section{REFERENCES}

1. Kamath SS, Kavitha M \& Swamy MJ. (2006). Beyond carbohydrate binding: new directions in plant lectin research. Organic and Biomolecular Chemistry. 4: 973-988.

2. Vakri A, Cummings RD, Esko JD, Etzler ME, Surolia A, Cummings RD. (2009). Essential of glycobiology. Chapter $29 \mathrm{~L}$ - type lectins. 2nd ed. Cold Spring Harbor (NY): Cold Spring Harbor Laboratory Press. p. 341-345.

3. Sharon, N \& Lis H. (2004). History of lectins: from hemagglutinins to biological recognition molecules. Glycobiology. 14(11), 53-62.

4. Sharon N. (1996). Carbohydrate- lectin interactions in infectious disease. Advances in Experimental Medicine and Biology. 408: 1-8.

5. Van Damme EJM, Lannoo N \& Peumans WJ. (2008). Plant lectins. Advances in Botanical Research. 48: 107-209.

6. Han JW, Jung MG, Kim MJ, Yoon KS, Lee KP \& Kim GH. (2010). Purification and characterization od a D-mannose specific lectin from the green marine alga, Bryopsis plumose. Phycological Research. 58: 143-150.

7. Khan F \& Khan MI. (2011). Fungal lestins: Current molecular and biochemical perspectives. International Journal of Biological and Chemical Science. 5: 1-20.

8. Peumans WJ, Zhang W, Barre A, Astoul CH \& BalintKurti PJ. (2000). Fruit specific lectins from banana and plantain. Planta. 211: 546-544.

9. Singh J \& Komboj SS. (2004). A novel mitogenic and antiproliferative lectin from a wild cobra lily, Arisaema flavum. Biochemical and Biophysical Research Communications. 318: 1057-1065.

10. Kaur A, Komboj SS \& Singh J. (2006). Isolation od a new lectin from the bulbs od Crinum latifolium (L.). Journal of Biological Sciences. 6: 9-14. 
11. Raja SB, Murali MR, Kumar NK \& Devaraj SN. (2011). Isolation and partial characterization od a novel lectin from Aegle marmelosfruit and its effect on adherence and invasion od Shigellae to HT29 cells. PloS One. 6: e16231-e16231.

12. Vasconcelos IM \& Oliveira JT. (2004). Antinutritional properties of plant lectins. Toxicon. 44(4), 385-403.

13. Nachbar MS \& Oppenheim JD. (1980). Lectins in the United States diet: A survey of lectins in commonly consumed foods and a review of the literature. American Journal of Clinical Nutrition. 33(11), 2338-2345.

14. Lorenzsonn V \& Olsen WA. (1982). In vivo responses of rat intestinal epithelium to intraluminal dietary lectins. Gastroenterology. 82: 838-848.

15. Sauvion N, Nardon C, Febvay G, Gatehouse AM \& Rahbe Y. (2004). Binding of the insecticidal lectin Concanavalin A in pea aphid, Acyrthosiphon pisum (Harris) and induced effects on the structure of midgut epithelial cells. Journal od Insect Physiology. 50: 1137-1150.

16. Kilpatrick DC. (1999). Mechanisms and assessment of lectin-mediated mitogenesis. Molecular Biotechnology. 11: 55-65.

17. Edelson PJ \& Cohn ZA. (1974). Effects of Concanavalin A on mouse peritoneal macrophages. Stimulation of endocytiy activity and inhibition of phagolysosome formation. Journal od Experimental Medicine. 140: 1364-1386.

18. Rocca JD. (2004). Lectins as Next Generation Mucoadhesives for specific tarheting of the gastrointestinal tract. Gastroinstestinal Target Drug Develop. 4: 12-19.

19. Wang Q, Yu LG, Campbell BJ, Milton J \& Rhodes JM. (1998). Identification of inact oeanut lectin in peripheral venous blood. Lancet. 352: 1831-1832.

20. Brady PG, Vannier AM \& Banwell JG. (1978). Identification of the dietary lectin, wheat germ agglutinin, in human intestinal contents. Gastroenterology. 75: 236.

21. Pusztai A, Clarke EMW \& King TP. (1979). The nutritional toxicity of Phaseolus vulgaris lectins. Proceedings of the Nutrition Society. 38: 115.

22. Kolberg J \& Sollid, L. (1985). Lectin activity of gluten identified as wheat germ agglutinin. Biochemical and Biophysical Research Communications. 130(2), 867-872.

23. Coppo R, Amore A \& Roccatello D. (1992). Dietary antigens and primary IgA nephropathy. Journal of American Society of Nephrology. 2(10), 173-180.

24. Marzo F, Alonso R, Urdaneta E, Arricivita FJ \& Ibanez F. (2002). Nutritional quality of extruded kidney bean (Phaseolus vulgaris L. var. Pinto) and its effects on growth and skeletal muscle nitrogen fractions in rats. Journal of Animal Science. 80(4), 875-879.

25. King TP, Pusztai A, Grandt G \& Slater D. (1986). Immunogold localization of ingested kidney bean (Phaseolus vulgaris) lectins in epithelial cells of the rat small intestine. Histochemical Journal. 18(8), 413-420.
26. Pusztai A, Olivera JTA, Bardocz S, Grant G \& Wallace HM. (1988). Dietary kidney bean lectin-induces hyperplasia and increases polyamine content of the small intestine. The Lectins, Biology, Biochemistry, Clinical Chemistry. Sigma Library, St Louis, Missouri. 6: 117-120.

27. Haas H, Falcone FHJ, Schramm G, Haisch K, Gibbs BF, Klaucke J, Poppelmann M, Becker WM, Gabius HJ \& Schlaak M. (1999). Dietary lectins can induce in vitro release of IL-4 and IL-13 from human basophils. European Journal of Immunology. 29(3), 918-927.

28. D’Adamo J \& Richards A. (1980). One Man's Food is Someone Else's Poison. Richard Marek Publisher.

29. Els J, Van Damme M, Pneumans W, Pusztai A \& Bardocz S. (1998). The Handbook of Plant Lectins: Properties and Biomedical Applications. John Wiley and Sons, New York.

30. Sharon A, Sathyanada N, Shubharani R \& Sharuraj M. (2000). Agglutination of human erythrocytes in food and medicinal plants, Database of medicinal plants. Karnataka State Council for Science and Technology.

31. Tommy J, Olsson S, Ahren B, Thorkild CB, Anita D \& Lindeberg S. (2005). Agrarian diet and diseases of affluence - Do evolutionary novel dietary lectins cause leptin resistance? BMC Endocrine Disorders. 5(10), 1-7.

32. Eroarome MA, Harinder PSM \& Klaus B. (1998). Nontoxic Variety of Jatropha curcas using Latex Agglutination and Haemagglutination Methods and Inactivation of Lectin by Heat Treatments. Journal of the Science of Food Agriculture. 77(3), 349-352.

33. Calder PC, Krauss-Etschmann S, de Jong E C, Dupont C, Frick JS \& Frokiaer H. (2006). Early nutrition and immunity - progress and perspectives. British Journal of Nutrition. 96(4), 774-790.

34. Raman BV, Radhakrishnan TM \& Rajagopal SV. (2005). Antibacterial and immunomodulatory studies on selected brown algal species of Visakhapatnam seacoast. Indian Journal of Microbiology. 45: 245-249

35. Sravani BM. (2011). Theses and dissertation. Studies on plant lectins as therapeutic agents. Department Of Biotechnology, Kuala Lumpur University, Vaddeswaram, Guntur, Andhra Pradesh, India.

36. Laurie CD, Ray AM \& George AB. (2010). Naturally Occurring Food Toxins. Toxins. 2(9), 2289-2332.

37. Matsumoto H, Shinzaki S, Narisada M, Kawamoto S \& Kawamoto K. (2010). Clinical application of a lectinantibody ELISA to measure fucosylated haptoglobin in sera of patients with pancreatic cancer. Clinical Chemistry and Laboratory Medicine. 48: 505-512.

38. Wearne KA, Winter HC, O'Shea K \& Goldstein IJ. (2006). Use of lectins for probing differentiated human embryonic stem cells for carbohydrates. Glycobiology. 16: 981-990.

39. Raja SB, Murali MR, Kumar NK \& Devaraj SN. (2011). Isolation and partial characterization of a novel lectin from Aegle marmelosfruit and its effect on adherence 
and invasion of Shigellae to HT29 cells. PloS One. 6: e16231-e16231.

40. Freire MDGM, Gomes VM, Corsini RE, Machado OLT \& de Dimone SG. (2002). Isolation and partial characterization of a novel lectin from Talisia esculenta seeds that interferes with fungal growth. Plant Physiology and Biochemistry. 40: 61-68.

41. Hoorelbeke B, Huskens D, Ferir G, Francois KO \& Takahashi A. (2010). Actinohivin, a broadly neutralizing prokaryotic lectin, inhibits HIV-1 infection by specifically targeting high-manose-type glycans on the gp120 envelope. Antimicrobial Agents and Chemotherapy. 54: 3287-3301.

42. Reis EAG, Athanazio DA, Cavada BS, Teixeira EH \& de Paulo V. (2008). Potential immunomodulatory effects of plant lectins in Schistosoma mansoni infection. Acta Tropica. 108: 160-165.

43. Poiroux G, Pitie M, Culerrier R, Segui B \& Van Damme EJM. (2011). Morniga G: A plant lectin as an endocytic ligand for photosensitizier molecule tarheting toward tumor-associated T/Tn antigens. Photochemistry and Photobiology. 87: 370-377. 


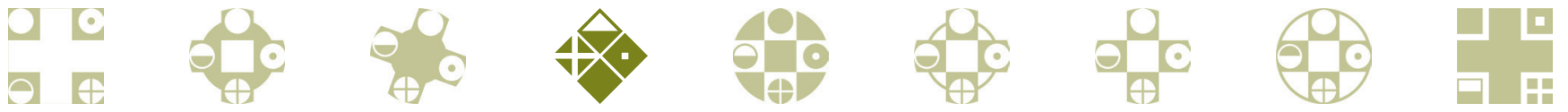

